\title{
Hitchhikers' guide to the legal context of protected area management plans in South Africa
}

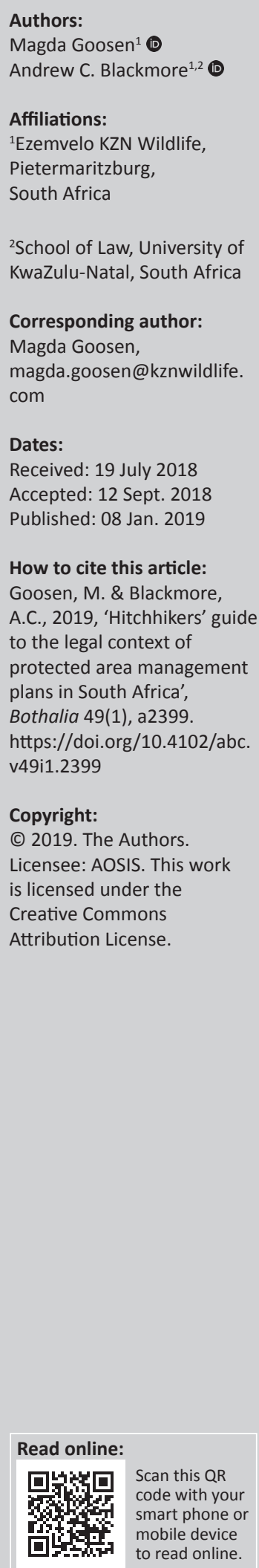

Background: Although formal protected areas in South Africa date back to the turn of the 19th century, requirements for protected area management plans only became mandatory a century later. Prior to the promulgation of the World Heritage Convention Act 49 in 1999, and subsequently the National Environmental Management: Protected Areas Act 57 in 2003, requirements for management plans were voluntary, and guidance to the plan's content was fragmented across an array of international, national and provincial policy instruments.

Objectives: As there has been little academic debate on the relevance and content of protected area management plans, an improved understanding of these plans, and the role they play in biodiversity conservation, is required.

Method: This article explores the evolution of the management plan, revisiting its historical and current legal context at international and national scales.

Results: Despite being the principal legislative framework for management plans, the World Heritage Convention Act and the National Environmental Management Protected Area Act did not consolidate the plethora of management plan requirements, and hence did not bring clarity when these conflicted or were ambiguous.

Conclusion: Legal provisions for management plans are highly fragmented. This risks plans not being complete, falling short of the requirement to ensure that protected areas fulfil the purpose for which they were established. A consolidation of relevant provisions, as well as emerging best practices is recommended. This may require the revision of South Africa's environmental law, to provide greater clarity on the contemporary understanding of the contribution of protected areas to conservation and the well-being of people (viz. the 'purpose').

\section{Introduction}

Formal protected areas in South Africa date to the turn of the 19th century, with the proclamation of the first (colonial) protected area in Africa in 1894 - the Pongola Nature Reserve in KwaZuluNatal (Figure 1). Following the formation of the Union of South Africa in 1910, nature conservation was retained as a predominant provincial competence. Although there were similarities, each of the then four provinces derived independently their own conservation legislation by way of 'Ordinances'. Many of these, albeit in amended forms, still remain in force. This legislation provided the necessary powers for the provinces to promulgate provincial protected areas, but did not require the then provincial conservation agencies to develop and implement protected area management plans. In 1926, the then national government established the National Parks Board through the National Parks Act 56 of 1926 (Republic of South Africa 1926). As with the provincial ordinances, this Act, and subsequent revisions thereof, was silent on the need for protected area management plans. Thus, prior to the promulgation of the World Heritage Convention Act 49 of 1999 (WHCA) and the National Environmental Management: Protected Areas Act 57 of 2003 (NEMPA) into law, there was no legal requirement, and hence obligation, for South African conservation agencies to draft and implement protected area management plans (Figure 1). Any drafting thereof, by the conservation agencies, was purely voluntary and was based on ad hoc intuitive, pioneering good practice, and was guided by the then developing international law pertaining to the conservation of biodiversity (Strydom \& King 2009). The drafting of these plans was therefore uncoordinated across the country, rarely incurred public scrutiny, and did not consider or reinforce the achievement of provincial or national goals or - given the international isolation prior to 1994 - international commitments (Strydom \& King 2009).

The re-acceptance of South Africa into the international community in 1994 introduced a variety of biodiversity conservation obligations into the country's environmental management. Thus, the 


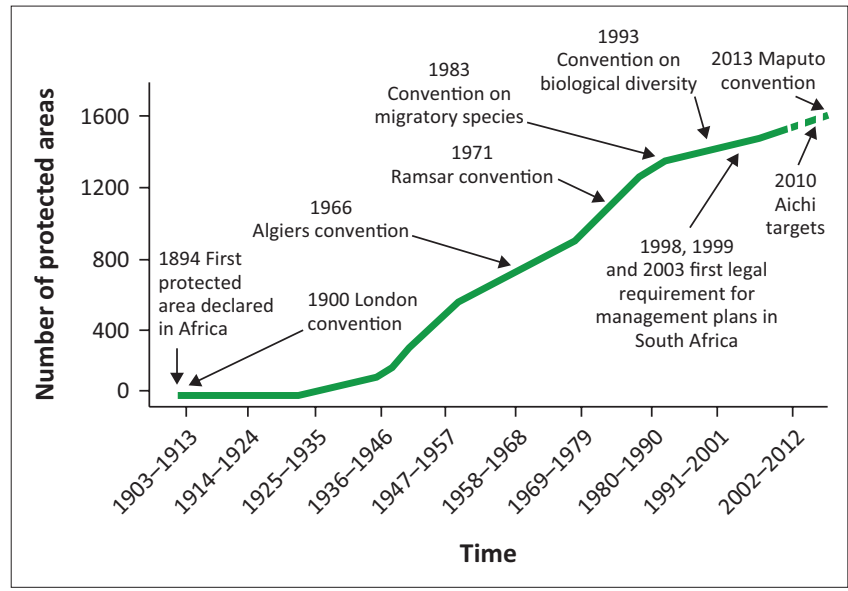

Source: IUCN \& UNEP-WCMC, 2018, The World Database on Protected Areas (WDPA), UNEPWCMC, Cambridge, UK, viewed 18 July 2018, from www.protectedplanet.net

FIGURE 1: A schematic representation of the accumulation of protected areas (South Africa), together with a timeline of the occurrence of key events that may have influenced the evolution of protected area management plans.

evolution and development of protected area management plans, at least from a legislative perspective, is relatively new and, as a result, has incurred little critical analysis and debate.

South Africa acceded to the Convention on Biological Diversity (CBD) in November 1995. That ushered in, inter alia, a target-focussed obligation to secure and protect representative samples of the country's biodiversity described as Aichi Targets in the 2010 Strategic Plan for Biodiversity (Figure 1). Aichi Target 11 requires contracting parties to the Convention to establish, by way of protected areas, a minimum of $17 \%$ of terrestrial and inland water, and $10 \%$ of coastal and marine areas by 2020 . These areas are required to be effectively and equitably managed in a manner that ensures their continued contribution to achieving the target and integration into the wider landscapes and seascapes (Ervin et al. 2010). The consequence of this Aichi Target for South Africa was the need for the expansion of protected areas - not only expansion in the size of existing protected areas, but a significant increase in the number of protected areas.

Against this legislative backdrop, the following question arises: what is the objective of protected area management plans and how does the legal framework prescribe and ensure that the derived plan is both relevant and achievable, and ultimately accomplishes the purpose of the protected area it was declared for?

\section{Analysis and discussion African multilateral context of protected area management plans}

The concern over declining wildlife numbers because of unregulated hunting led to the drafting of the Convention of the Preservation of Wild Animals, Birds and Fish in Africa (1900 London Convention) (Blackmore \& Trouwborst 2018). Although this Convention never came into force, as most signatory states failed to ratify it (Selier et al. 2016), it set out the foundation for the then colonial powers to influence the administration of the colonies in Africa to establish 'reserves' of 'sufficient large tracks of land which have all the qualifications necessary as regards food, water and, if possible, salt, for preserving birds or other wild animals' (Article 2[5]).

This article further prescribed that these areas had to be managed in a particular manner that affords them the 'necessary quiet during the breeding time', and that a prohibition is enforced making it unlawful 'to hunt, capture, or kill any bird or other wild animal except those which shall be specially exempted from protection by local authorities'. In so doing, the 1900 London Convention anticipated that the authority would need to actively make provision for and thereafter manage the protected area, to achieve at least the above-mentioned two outcomes. The theme of establishing protected areas and managing them for the common good was significantly enhanced by subsequent revisions of the 1900 London Convention, and, in particular, the 1966 Algiers Convention (Figure 1). Article IX (2) of the Algiers Convention (African Convention on the Conservation of Nature and Natural Resources 1966) required signatory states to, inter alia, ensure that the conservation of species and their habitats took place within the 'framework of land-use planning and of sustainable development'. This convention further required its signatories to 'manage plant and animal populations inside conservation areas according to the objectives of such areas' (Article IX 2[a]). Furthermore, Article XII (1) required such management must 'preferably' be within a 'framework of environmental and natural resource policies'.

This approach to manage protected areas was carried through and enhanced (drawing on the already established global multilateral agreements, e.g., the CBD) in the revision of the 1966 Algiers Convention in Maputo in 2003 - to form the (revised) African Convention on Conservation of Nature and Natural Resources (the Maputo Convention).

The Maputo Convention sets in place a wide range of objectives, and many of these are multi-faceted and require predefined and adaptive management strategies over extended periods of time (Figure 1). Although not explicitly stated, it stands to reason, that given the need for consistency from one manager to the next, such management complexities can only be efficiently achieved through a robust protected area management plan. The Maputo Convention further touches on the broad purpose of a protected area in that it defines a conservation area to be any protected area 'designated and managed mainly or wholly for one of the following purposes' (Article V [6]):

1. science or wilderness protection (strict nature reserves and wilderness areas)

2. ecosystem protection and recreation (national parks)

3. conservation of specific natural features (national monuments)

4. conservation through management interventions (habitat and species management areas) 
5. landscape/seascape conservation and recreation (protected landscapes and seascapes)

6. the sustainable use of natural ecosystems (managed resource protected areas).

Article X II (1)(a) of the Maputo Convention encourages the Southern African Development Community (SADC) states to establish and maintain (manage) conservation areas within a:

framework of environmental and natural resources policies, legislation and [...] in order to ensure the long-term conservation of biological diversity [...] and of the habitats that are critical for the survival of such species. (Article X II [1])

Interestingly, this Article limits the conservation focus of the member states to biodiversity that is only represented within areas of their jurisdiction, is threatened, or of special scientific or aesthetic value, and those 'habitats which are critical for the survival of such species'. It appears, therefore, that the Maputo Convention specifically excludes $e x$ situ conservation of species not indigenous to the member state, and possibly those species whose home-ranges extend marginally into a member state's jurisdiction. Conservation of these species is, thus, limited to those states in which they predominate. In this regard, the Convention appears not to support, if not impede, the establishment of a protected area that specifically includes those species (and their habitats) that are considered either common or vulnerable, and are not reasonably of special scientific or aesthetic value. In so doing, the Maputo Convention seeks to constrain the purpose and scope of a protected area to those land and seascapes that are essential for the conservation of biodiversity within a country. The management plan, therefore, would reasonably be expected to primarily embody the management of these land and seascapes.

Finally, the Maputo Convention recognises the importance of a buffer zone to maintain the integrity of a protected area. In this, the state party is required to establish a buffer zone to 'control activities outside conservation areas which are detrimental to the achievement of the purpose for which the conservation areas were created' (Article XII [4]). The inclusion of this buffer zone requirement within the provisions of Article XII suggests, therefore, that the buffer is considered to be part of the protected area and hence needs to be included in the management plan.

\section{Global multilateral context of protected area management plans}

\section{Convention on biodiversity}

Parallel to, if not causal to, the inclusion of the abovementioned biodiversity conservation and protected area establishment provisions in the Maputo Convention, CBD views protected areas as the foundation with respect to the conservation of biodiversity. The CBD defines a protected area as a 'geographically defined area, which is designated or regulated and managed to achieve specific conservation objectives' (Article 2). It would thus be a common cause for the protected area management plan to include the necessary management actions that would achieve those specific conservation objectives (Figure 1). The purpose and scope of the management plan is further defined by the encouragement of Parties to the convention to, inter alia, 'establish a system of protected areas or areas where special measures need to be taken to conserve biological diversity', and to 'develop, where necessary, guidelines for the selection, establishment and management of protected areas or areas where special measures need to be taken to conserve biological diversity' (Article 8). As such, the management plan for individual protected areas would need to include those actions that would contribute to the achievement of the purpose of establishing the protected area. The CBD further encourages Parties to 'promote environmentally sound and sustainable development in areas adjacent to protected areas (buffer zone) with a view to furthering protection of these areas' (Article 10). As with the Maputo Convention, it appears that the CBD sees the buffer zone as an integral part of the protected area, and, as such, it should be incorporated into the protected area management plan. This inclusion would naturally enable the setting of specific goals and targets for the buffer and the achievement thereof as agreed to by the CBD Conference of Parties - Decision VII/28. The integration of the buffer-zone requirement into the protected area management plan would facilitate the integration of the protected area into the broader landscape, seascape and cross-cutting sectors, as a means of maintaining or improving the integrity of the protected area. The extent to which the management plan would facilitate this integration beyond the requirement for a buffer zone is uncertain. Certainly, in a South African context, such requirement would most likely be better placed in the municipal sectoral plans, and the integration of the protected area into the broader municipal landscape, while relevant, is outside the scope of this paper.

In addition to the establishment of new protected areas, the CBD encourages Parties to expand existing protected areas to not only incorporate key neighbouring biodiversity elements, but also to increase the viability of a protected area as a transient or seasonal destination for migratory species (Goal 1.1). Thus, the management plan would need to consider the neighbouring areas of the protected areas that are important from a resident species or biodiversity habitat perspective, key habitats for migratory species, as well as increasing viability of the protected area. This consideration would naturally include those management actions required to ensure that these areas are sustained in a natural state and their valuable biodiversity attributes are safeguarded - and would ultimately serve protected area expansion target areas.

Goal 1.4 of the CBD speaks directly about the improvement of site-based protected area planning and management, and specifically the need for a management plan, which is scientifically based and participatory in development and implementation. This goal also links the effective management of protected areas to the development and implementation of the management plan, through a process of active stakeholder participation and adaptive management. 


\section{Convention on wetlands of international importance (Ramsar Convention)}

South Africa, being a contracting party to the Ramsar Convention (IUCN 1972), is encouraged to incorporate important wetlands into its network of protected areas (Figure 1). For a wetland to be listed by the Secretariat of the Convention as a wetland of international importance, the wetland ought, although not an obligatory action, to be declared a nature reserve (Article 4 [1]). Furthermore, the Convention requires the Parties to 'provide adequately for (the) wardening' (Article 4 [1]) of at least the wetlands listed or included into the network of protected areas, and to ensure that each of these protected areas is managed and researched by competent personnel (Article 4 [5]). It is uncertain whether the protected area management plan would necessarily include these matters, as they are best placed in the administrative and policy framework of the management authority that is referenced in the site's management plan. The Convention, however, in Article 4 (4), specifies that 'The Contracting Parties shall endeavour through management to increase waterfowl populations on appropriate wetlands'. Hence, the management plan for these sites should include an objective toward and management interventions aimed at achieving this requirement. The purpose of the protected area outlined in the management plan therefore should include the recovery and maintenance of waterfowl habitats (Figure 1).

In 2002, the Convention established specific guidelines for the management planning of Ramsar sites (IUCN 2002). The guidelines placed a strong emphasis on the management plan as part of an overarching planning process that provides for adaptive management, objectives, outcomes and integrated monitoring. In this, these guidelines require the management authority to develop a specific management plan for the wetland, and that this plan should be integrated into the protected area management plan and into relevant spatial and economic sector plans at local, regional and national scales (COP8 - Resolution VIII). As a result, these guidelines not only set in place a requirement for a protected area management plan, but also provide clear guiding principles as to the content of the management plan. The following functions of the protected area management plan were identified in the 2002 guidelines:

1. identification of management objectives

2. identification of factors that influence or are influenced by features

3. conflict resolution

4. identify monitoring requirements

5. management interventions to achieve the objectives

6. maintain continuity in managing sites

7. source financial resources for the implementation of the plan

8. mechanisms for stakeholder communication

9. accountability in the implementation of the plan

10. compliance with policy frameworks.

These functions, together with the requirements of the CBD as they relate to management plans, would later be incorporated into the NEMPA 57 of 2003.

\section{World Heritage Convention}

The intention of the World Heritage Convention (WHC) (United Nations Educational, Scientific and Cultural Organization [IUCN] 1972) was to create a global framework for the protection and conservation of natural and cultural heritage that was considered to be of 'outstanding universal value' (OUV). The management plan for a world heritage site (WHS) should, therefore, as a minimum, provide for the permanent protection of the OUVs on which the inscription of the WHS was based (Figure 1). The inscription of a site onto the World Heritage List by the World Heritage Committee of the UNESCO depends on whether 'effective and active measures' can be taken 'for the protection, conservation and presentation of the cultural and natural heritage' (Article 5). The plan, therefore, must contain those management actions that reasonably guarantee the integrity and authenticity of the OUVs. To achieve this, the WHC sets in place guidelines (UNESCO 1995) that, inter alia, enable both the drafting and implementation of WHS management plans, and a system of reporting the state of conservation of the site and the achievement of the management plan (World Heritage Convention 1972). Thus, to remain compliant with the Convention, it would be essential that the WHS management plan predominantly complies with the provisions of these operational guidelines.

Furthermore, both the Convention and the operational guidelines recognise that the OUVs may not always remain fixed within the WHS. Some OUV may be moveable (e.g. archaeological artefacts) or may become moveable over time requiring them to be conserved in a facility outside the site (Jakubowski 2004). For the management plan to be considered compliant with the provisions of the Convention, it would need to include procedures and actions required to ensure that the integrity of ex situ OUV artefacts is safeguarded. Where third parties become the custodian of the OUV and other protected area artefacts, the management plan would need to include, or at least refer to, a mandatory custodianship agreement (Shefi \& Veth 2015).

\section{Convention on Migratory Species of Wild Animals}

The Convention on Migratory Species of Wild Animals (CMS), also known as the Bonn Convention, was signed in 1979 and entered into force in 1983, under the United Nations Environment Programme. Although this Convention is focussed on the protection of migrant species across international boundaries, it is important to recognise that protected areas play a critical role in the conservation and protection of these species. Where this is deemed to be relevant, and where specific agreements have been made between rangeland counties (e.g. the Conservation of African-Eurasian Migratory Waterbirds [AEWA]), specific provisions need to be incorporated into the protected area management plan in order to comply with this Convention.

\section{South African context for protected area management plans}

The requirement of protected area management plans, and of all South African legislative provisions, is rooted in the 
Constitution of the Republic of South Africa (Republic of South Africa 1996), and specifically in Section 24 (the Environmental Right) which states that:

Everyone has the right

1. to an environment that is not harmful to their health or wellbeing

2. to have the environment protected, for the benefit of present and future generations, through reasonable legislative and other measures that:

(a) prevent pollution and ecological degradation

(b) promote conservation

(c) secure ecologically sustainable development and use of natural resources while promoting justifiable economic and social development.

Subsection (2) of the Environmental Right embeds the ethos for the establishment of protected areas, in that they protect South Africa's biodiversity for the benefit of current and future generations. It stands to reason then that the management of the protected area, in order to remain within this constitutional imperative, must promote not only the conservation of biodiversity, but also provide for the persistence of these protected areas over time. The same philosophy applies to any development or recreational activities within a protected area in that these activities cannot compromise the ecological integrity of the biodiversity or the protected area as a whole (Blackmore 2014). The Environmental Right is primarily operationalised through South Africa's environmental legislation and, in particular, the National Environmental Management Act 107 of 1998 (NEMA).

\section{National Environmental Management Act 107 of 1998}

Two chapters within NEMA (Republic of South Africa 1999) have direct relevance to protected area management plans (Figure 1). Chapter 1 specifies the environmental management principles that must be applied by the government in decision-making (viz. adopting a protected area management plan for implementation that may significantly affect the environment). These principles serve as a 'general framework within which environmental management and implementation plans must be formulated' (Section 2 [1] [b]). National Environmental Management Act 107 of 1998 separates the principles into three synergistic, and, in places, overlapping categories. The first category places all people (inclusive of future generations) at the forefront of environmental management - in that decisions taken must reflect people's 'physical, psychological, developmental, cultural and social interests equitably' (Section [2][2]). That is to say that the protected area management plans, within the context of biodiversity conservation, must be balanced and take into consideration, if not be reflective of, South Africans' multicultural character, as well as the potential interests and expectations of those yet to be born. The second category provides for development that must be socially, environmentally and economically sustainable (Section [2] [3]). In the context of protected areas, this principle not only requires that all development needs to be ecologically sustainable and reflective of South African society, but also needs to be economically viable over time. In essence, the protected area, or at least the commercial development within the protected area (i.e. tourism facilities), should be self-sustaining and not cause an ongoing financial burden on the protected area and therein the state. The third category provides for those principles that evoke sustainable use of the environment, best practice and sound governance (Section 2 [4]). These principles include, inter alia, avoidance of disturbance and remediation where significant damage has occurred, safeguarding the integrity of ecosystems, the precautionary and polluter-pays principles and the public trust doctrine. While it is not a prerequisite for the environmental management principles to be explicitly included in the protected area management plan, it is a common cause that the plan must include sufficient details to demonstrate that the principles have been considered and applied. The management plan would, therefore, ideally need to include sufficient reference to these principles that bind the management authority for the protected area to consider and apply them when drafting and implementing the plan.

The National Environmental Management Act also provides for all organs of state to apply 'Environmental implementation plans and management plans' to, inter alia, 'secure the protection of the environment across the country as a whole' (Chapter 3). The purpose of these plans is to consolidate relevant, inter- and intra-discipline policies, plans and programmes that significantly affect the environment, and to provide a foundation for co-operative governance for organs of state that have a mandate in the management of the environment concerned. The relevance of this chapter lies therein that a number of protected areas in South Africa have a dual persona - they may be a national park, nature reserve or WHS, and also may be proclaimed as a state forest, state dam, cultural heritage site or mountain catchment area. In such cases, the area concerned may be subject to varying and potentially conflicting legislative requirements, which will need to be integrated into one coordinated (as the case may be) environmental implementation or management plan. These plans are, inter alia, required to make explicit the functions exercised by the relevant organs of state, the norms and standards that are to be maintained and the policy requirements. In so doing, this chapter of NEMA specifies, in part, the content and purpose of management plans that apply to these protected areas.

Finally, Chapter 6 of NEMA provides for the incorporation into the country's environmental decision-making framework provisions derived from international environmental instruments that are binding on the state, which have not already been included into the country's environmental legislation. In such cases, the protected area management plans would need to consider the provisions of relevant multilateral environmental instruments that South Africa has entered into. The protected area management plans would also need to be revised at a frequency that allows for the consideration and incorporation of subsequent decisions adopted by the Conference of Parties for that particular 
instrument. Furthermore, Chapter 6 also allows, as does the principles for environmental management, for the consideration of international soft law - i.e. that which is not binding on the state - to be considered as a guide and incorporated, where relevant, into environmental decisionmaking (Section 25).

The National Environmental Management Act provides for several specific environmental statutes. Two of these explicitly dictate the requirement of protected area management plans, as well as the purpose and content of these plans:

- National Environmental Management: Protected Areas Act 57 of 2003

- World Heritage Convention Act 49 of 1999.

In addition to these, the following specific environmental statutes may have direct relevance to the protected area management plans, and thus relevant provisions need to be catered for in the protected area management plans:

- National Environmental Management: Biodiversity Act 10 of 2004 (NEMBA)

- National Environmental Management: Integrated Coastal Management Act 24 of 2008 (NEMICMA)

- Mountain Catchment Act 63 of 1970

- National Water Act 36 of 1998

- National Forest Act 84 of 1998

- National Heritage Resources Act 25 of 1999.

The contribution of these eight statutes to the content of protected area management plans is discussed below. These statutes further provide for Regulations that may have direct relevance to the content of the management plan, for example, the Alien and Invasive Species Regulations. Although paramount, they are subject to change as circumstance dictates and thus are not considered in this paper.

\section{National Environmental Management: Protected Areas Act 57 of 2003}

The primary obligation for each protected area to have an adopted management plan is grounded in Section 40 of NEMPA (Figure 1). This section obligates the management authority to, inter alia, manage the protected area 'exclusively for the purpose for which it was declared, the protected area management plan and in accordance with the provisions of NEMBA and any other applicable legislation' (Section 40). It is, therefore, vital that the management plan clearly identifies the purpose for which the protected area was declared, to provide for the appropriate management. While this requirement may be easily tractable, it does pose a 'legal' conundrum.

Firstly, the NEMPA (Republic of South Africa 2003) specifies 12 wide-ranging purposes of protected areas (Section 17), but is silent on whether such purposes are the sole basis for which a protected area may be declared. The Act is, furthermore, silent on whether the specified purposes have a retrospective application, and if they will be in addition to or replace the original purposes the existing protected areas were established for. Secondly, there is no requirement in the Act for the declaration notices to include the reason for which an area is to be set aside as a protected area. Thus, the declaration notices contemplated in Chapter 3 of the Act are likely to be mute on the conservation purpose of the protected area. Even if the purpose for declaration is stated in the gazetted notice, the founding conservation purpose for a protected area in the original declaration may not necessarily be consistent with and accurately reflect the protected area's current contribution to the network of protected areas representing South Africa's biodiversity. As circumstances change (i.e. discovery of more important values of the protected area, loss of biodiversity elsewhere, change in the threatened status of components of biodiversity and so on), the conservation contribution, as well as the purpose of the protected area, is likely to change with time. For example, the Tembe Elephant Park was established to protect the local communities from the then free-roaming elephant population (Blackmore 2014). Subsequent to its establishment, it was discovered that the protected area housed more significant biodiversity values in terms of critically endangered and endemic sand forest (Matthews 2001) than the conservation of elephant. Both Lagendijk et al. (2011) and Kirkwood and Midgley (1999) found that the disturbance caused primarily by elephants to sand forest was a major threat to the conservation status and persistence of this habitat. Thus, to stringently manage Tembe Elephant Park exclusively for the purpose it was declared for as a protected area would risk both the sand forest habitat and its endemic species becoming extinct. Similarly, Davies (2000) indicates that the Madikwe Game Reserve was established 'to stimulate ecological sustainable economic activity based on wildlife through joint venture operation between government, private sector and local people for the benefit of the region'. In keeping with this purpose, it is therefore, although inconceivable from a conservation and protection of biodiversity perspective, plausible that an abattoir and a chromium-based tannery could be established in the protected area. These examples both highlight the potential vulnerability of protected areas that have declaration notices or management plans that specify a very narrow or specific purpose, or a purpose that may be inconsistent with the listed purposes for establishing a protected area.

To resolve the conundrum and therein counter outdated purposes or a misinterpretation of a declared purpose which may lead to inappropriate use and development in the protected area, NEMPA (Republic of South Africa 2003) in section 41 obligates the management (and therefore its use) of the protected area to be constrained:

to ensure the protection, conservation and management of the protected area concerned in a manner which is consistent with the objectives of this Act and for the purpose it was declared. (p. 32)

Where the interpretation of the declared purpose is in conflict with the objectives of NEMPA (viz. stand to threaten the 
integrity of the protected area or the biodiversity therein), the objectives of the Act and the listed purposes in section 17 should prevail. The management plan, therefore, must be written in a manner that promotes the objectives of the Act and the listed purposes of a protected area.

The objectives of the Act that concern the content of a management plan include the conservation of biodiversity, provision of a mechanism for the sustainable use for the benefit of people and participation of neighbouring communities therein, and to provide for co-operative governance where the protected area involves an overlapping mandate with various organs of state (e.g. where the protected area includes significant heritage, or a state dam) (Section 2).

Section 12 of NEMPA provides for protected areas that are reserved or protected, in terms of alternate legislation, for 'any purpose for which an area could in terms of this Act be declared' to be deemed a protected area under NEMPA. It can be assumed, therefore, that the 'purpose' stated in this section is equal to the 'purposes' for protected areas stated in Section 17 of the Act.

\section{World Heritage Convention Act 49 of 1999}

The World Heritage Convention Act 49 of 1999 (WHCA) was established to incorporate the WHC into South Africa's legislative framework (Republic of South Africa 1999) and to provide for its implementation (Figure 1). Preceding NEMPA, the WHCA became the first statute to require a management plan - termed an 'integrated management plan' (IMP) specifically for WHS. The Act set out the fundamental principles that relate to transparency and participation in and benefits from WHS, and these principles set the scene for the purpose of IMPs, and how they would be developed and implemented (Sections 3 and 4).

The concept of safeguarding the public trust entity was first recognised as a fundamental principle in the WHCA (Republic of South Africa 1999) sets out principles in section 4 - providing that the:

cultural and natural heritage is held in public trust for the people, the beneficial use of cultural and environmental resources must serve the public interest and the cultural and natural heritage must be protected as the common heritage of the people. (p. 6)

The fundamental principles of WHCA not only ensured transparency and participation in the planning and management of this type of protected area but also juxtaposed two very different and specialised fields: natural heritage and cultural heritage. The management of WHS, therefore, may include both natural and cultural heritage attributes, the management of which must be integrated into one plan to ensure that conflicts in management do not arise.

Furthermore, the IMP is required to be harmonised not only with provisions of the WHC but also with those plans specified by NEMA, various sectoral plans adopted by other organs of state, and regional and municipal development plans (Section 22).

Finally, the WHCA specifies that the IMP includes, inter alia, as a minimum, a coordinated policy framework, performance criteria, an implementation programme, mechanisms for public and expert participation, provisions where specific management actions are required to conserve elements within the park and any other matter prescribed by law or directed by the minister.

\section{National Environmental Management Biodiversity Act 10 of 2004}

The objectives of the NEMBA (Republic of South Africa 2004) are threefold, two of which relate directly to the management of protected areas and, therefore, management plans. The first objective is the 'protection of species and ecosystems that warrant national protection' (some of which are contained within formally protected areas), and the 'sustainable use of indigenous biological resources'. As with NEMPA, this Act formally brings into South Africa's environmental law many of the international obligations that are contained in the Convention on Biodiversity, the Convention on Migratory Species and the Convention on Trade in Threatened and Protected Species. Where relevant, these obligations would need to be catered for in the protected area management plan.

Chapter 3 of the Act provides for 'integrated and co-ordinated biodiversity planning', and this planning will ultimately set out national biodiversity targets, more importantly in terms of protected areas, guide where these critical biodiversity areas that require formal protection would be. Secondly, this chapter deals with the monitoring of various components of biodiversity and the promotion of biodiversity research two aspects that are key components in management plans in addressing adaptive management and best practice in protected areas.

\section{National Environmental Management: Integrated Coastal Management Act 24 of 2008}

The National Environmental Management: Integrated Coastal Management Act (NEMICMA) (Republic of South Africa 2008) relates to the appropriate management of the coastal environment - including the management of estuaries. In certain instances, protected areas have been established in these coastal landscapes and may contain estuaries entirely or partially within their boundaries. For these circumstances, the management plan for the protected area will have to be compliant with both NEMPA and NEMICMA, in that, the latter makes provision for the development of estuarine management plans. Furthermore, estuary management plans must be drafted (and hence the estuary is to be managed), in accordance with the National Estuarine Management Protocol and its minimum requirements (Section 33). The Act requires the Protocol to include a strategic vision and objectives for the estuary, standards for estuary management, management procedures and minimum requirements of the estuary. Naturally, the protected area management would need to include these 
requirements. As the Protocol applies to estuaries at a national level, a conflict may arise between the purposes and objectives, and the management of the estuary and the protected area of which it forms a part. In these circumstances, given that both NEMPA and NEMICMA claim superiority, and in the absence of a legal resolution, it would be obligatory for the protected area management plan to resolve potential conflicts and to set in place parity between NEMPA and NEMICMA requirements. Should parity not be achieved, the protected area management plan risks not being adopted and hence not implemented, and therefore may potentially fall short of the constitutional conservation imperatives discussed above.

\section{Mountain Catchment Act 63 of 1970}

The relevance of this legislation for protected areas lies in the previously referred to double persona that protected areas may have. It is common for protected areas to include declared mountain catchment areas or vice versa.

The Mountain Catchment Act 63 of 1970 (MCAA) provides 'for the conservation, use, management and control of land situated in mountain catchment areas'. The definition of a mountain catchment area as per this Act is 'any area declared under Section 2 to be a mountain catchment area'. The term 'management and control' implies that the management of these areas should be directed at achieving the purpose for which these areas were declared (as a mountain catchment area). This purpose includes, inter alia, 'conservation, use, prevention of soil erosion, the protection and treatment of the natural vegetation' (Section 3 [i] aa \& bb), including the eradication of invasive vegetation. It is thus a common cause, in terms of this Act, that a management plan should, at least, demonstrate the intent of the management authority for the mountain catchment area to achieve these objectives. Notwithstanding the desirability of this management plan, the Act specifically prescribes for a dedicated 'fire protection plan', for the management of fire within all or part of the mountain catchment area. In terms of fire management as prescribed by the Act versus fire management inside protected areas, there is a discrepancy in terms of the purpose of fire management. In the case of the mountain catchment fire protection plan, the focus of fire management is on the protection of the catchment against fires. In the case of a protected area, and in line with fire management requirements incorporated in the protected area management plan, the focus is on both protection from unplanned burning and recognising that fire may be an essential determinate of the protected area's biodiversity. Thus, the use of fire is a key management tool to sustain the biodiversity of the protected area. Furthermore, the MCAA provides for what appears to be a regulated 5-km-wide 'buffer' (Section 3) surrounding the mountain catchment area. The creation and management of this buffer would naturally be managed in support of the mountain catchment area and in accordance with the objectives of the Act, and as such, this must be included in the management plan of the protected area. In its essence, this regulated 5-km-wide 'buffer' would be equivalent to the buffer envisaged around a protected area.
The additional protection and underlying principles of conservation, soil erosion prevention, invasive species control, and protection of vegetation that are contained in this Act, is complementary to other protected area legislation. Although specific management of the area as it pertains to fire management, as contained in the protected area management plan versus in the fire protection plan of the mountain catchment area, may create conflicting objectives. Unlike the potential conflict between NEMPA and NEMICA, the MCAA is silent on its supremacy over other legislation. Thus, in a case of conflict between the two Acts, from a legal perspective the provisions of NEMPA would prevail. Nonetheless, not to comply substantially with MCAA risks the mountain catchment designation being withdrawn.

\section{National Forest Act 84 of 1998}

Some of South Africa's earliest conservation efforts pertain to the protection of forest areas - as early as Jan van Riebeeck's first ventures into Southern Africa. Britton (2006) indicated that the 'first regulations were issued for the systematic management of the indigenous forest' in 1883. Historically, many natural forests in South Africa, and specifically in KwaZulu-Natal province, were declared as protected forest areas in the early to mid-1900s - for example, Giant's Castle was established under Government Notice No 356 of 1907, in terms of various acts that were later consolidated under the National Forest Act 84 of 1998. A key provision of this Act, given it preceded the NEMPA by five years, was the formal establishment of protected areas specifically for natural forests. As with NEMPA, this Act specifically requires the forest protected areas to be managed to achieve the purpose for which they were established. This achievement may be regulated by the political head for natural forests, through specific rules. These rules, as well as the means to achieve them, would need to be included in the protected area management plan.

The National Forest Act, Chapter 4 (19), provides for public access (for recreational use, recreation, education, culture or spiritual fulfilment) of all state forests, including forest protected areas, as well as the 'voluntary' granting of public access for these activities to forests that are privately owned. Access to forests by the public is however not necessarily absolute. The Act recognises that a protected area may be established as a sanctuary, protected from being disturbed by public access, or is sensitive to public use. To provide for such protection, Section 20 (3) of the Act provides for the political head of forests to restrict 'entry into any area protected for environmental purposes'. This 'restrictive purpose' may be additional and complimentary to, the original purpose for which the forest was declared as a protected area.

The protected area management plan, therefore, would need to include the original purpose, any restrictive purposes and specific rules, and how these will be effective. The management plan would also need to provide for, where necessary, access and any reasonable public use of the protected area. 


\section{National Heritage Resources Act 25 of 1999}

The public trust principle was also embedded into the National Heritage Resources Act (Republic of South Africa 1999) (NHRA), which emphasises the conservation of heritage resources 'so that they may be bequeathed to future generations' (National Heritage Resource Act 1999). The Act makes provision for the designation of provincial and national heritage sites (Chapter 2), and for these heritage sites to be managed in accordance with a management plan (Section 9). At least some of these heritage resources may be located within protected areas that have been established for the conservation of biodiversity; these protected areas and therefore their management plans, now being of dual persona, would have to comply with the requirements of natural and cultural heritage.

\section{Conclusion}

Protected area management plans have evolved out of 150 years of conservation history, which has culminated in three overlapping functions. The first function is to ensure that protected areas are appropriately managed - at least for the purpose for which they were established. Secondly, they provide a mechanism for consistency in management actions from one manager or management authority to another. Thirdly, the management plan serves as an omnibus for the public to ascertain that a protected area is being managed in their best interests and that of future generations.

Contrary to expectations, NEMPA does not provide a onestop-shop for management plans and protected areas in South Africa. In fact, there exist various legislations to guide and direct the management of various types of protected areas, and the development of management plans for these areas. This legislation provides a framework for the integration of various planning mechanisms and supports the principle of public trust, whereby the state is held accountable for securing natural and cultural heritage for current and future generations.

While protected area management plans are mainly prescribed in the WHCA 49 of 1999 and the NEMPA57 of 2003, these two statutes do not embrace the full range of requirements to be included in these plans. This review has discovered that the legal provisions, both domestic and international laws, are fragmented and thus are highly complex. This circumstance risks management plans not being complete, therein falling short of the requirement to ensure that the protected areas fulfil the purpose for which they were established. It is thus recognised that comprehensive protected area management plans are crucial for the conservation of autochthonous and migratory biodiversity, as well as its heritage and other values. To reduce the complexity of protected area management plans, it is recommended that the relevant provisions within the plethora of statutes and African and global multilateral environmental agreements, as well as emerging best practices, should be consolidated. This may require the revision of South Africa's environmental law to remove this complexity, and therein provide for greater clarity on the contemporary understanding of the contribution of protected areas to conservation and thus the well-being of people (viz. the 'purpose').

\section{Acknowledgements}

The authors would like to thank Ezemvelo KZN Wildlife for their support.

\section{Competing interests}

The authors declare that they have no conflicts of interest with regard to the writing of this article.

\section{Authors' contributions}

M.G. initiated this article and undertook the primary research and analysis. A.C.B. provided legal interpretation and guided the drafting of the article.

\section{References}

African Convention on Conservation of Nature and Natural Resources (Revised Version), viewed 12 June 2018, from https://au.int/en/treaties/africanconvention-conservation-nature-and-natural-resources-revised-version

Blackmore, A.C., 2014, 'The interplay between the public trust doctrine and biodiversity and cultural resource legislation in South Africa: The case of the Shembe Church Worship Site in Tembe Elephant Park in KwaZulu-Natal', Law, Environment and Development Journal

Blackmore, A.C. \& Trouwborst, A., 2018, 'Who owns and is responsible for the elephant in the room? Management plans for free-roaming elephant in South Africa', Bothalia 48(2), a2271, viewed 13 June 2018, from https://abcjournal.org/ index.php/abc/article/view/2271

Britton, P.E.N., 2006, 'A short history of forestry in South Africa', BSc thesis, Stellenbosch University, South Africa

Convention for the Preservation of Wild Animals, Birds, and Fish in Africa, 1900, viewed 12 June 2018, from http://iea-archive.uoregon.edu/page.php?file=home. htm\&query=static

Convention on Biodiversity Secretariat, 2010, The strategic plan for biodiversity 20112020 and the Aichi biodiversity targets, document UNEP/CBD/COP/DEC/X/2, secretariat of the Convention on Biological Diversity, Nagoya, Japan

Davies, R., 2000, 'Madikwe Game reserve: A partnership in conservation', in H. Prins, J. Grootenhuis \& T. Dolan (eds), Wildlife conservation by sustainable use, Conservation Biology Series 2, Springer, Dordrecht

Ervin, J., Mulongoy, K.J., Lawrence, K., Game, E., Sheppard, D., Bridgewater, P. et al., 2010, 'Making protected areas relevant: A guide to integrating protected areas into wider landscapes, seascapes and sectoral plans and strategies', CBD Technical Series 44(5), 1-94

IUCN \& UNEP-WCMC, 2018, The World Database on Protected Areas (WDPA), UNEPWCMC, Cambridge, UK, viewed 18 July 2018, from www. protectedplanet.net

Jakubowski, K.J., 2004, 'Geological heritage and museums', Polish Geological Institute Special Papers 13, 21-28

Kirkwood, D. \& Midgley, J.J., 1999, 'The floristics of Sand Forest in northern KwaZuluNatal, South Africa', Bothalia 29(2), a602, viewed 20 June 2018, from https:// abcjournal.org/index.php/ABC/article/view/602

Lagendijk, D.G., Mackey, R.L., Page, B.R. \& Slotow, R., 2011, 'The effects of herbivory by a mega-and mesoherbivore on tree recruitment in Sand Forest', South Africa. PLoS One 6(3), e17983, viewed 12 June 2018, from http://journals.plos.org/ plosone/article?id=10.1371/journal. pone.0017983

Matthews, W., 2001, 'Maputoland's Tembe elephant national park - A little known reserve with many natural secrets', viewed 12 June 2018, from http://www. africaelephants.com/ecology.htm

International Union for Conservation of Nature (IUCN), 1972, 'Convention on wetlands of international importance especially as waterfowl habitat', Ramsar, Iran

International Union for Conservation of Nature (IUCN), 2002, New guidelines for management planning for Ramsar sites and other wetlands, Resolution VIII. 14, Valentia, Spain.

Republic of South Africa, 1926, National Parks Act 56. Government Gazette, Vol. 130, No. 5096

Republic of South Africa, 1996, Constitution of the Republic of South Africa, Act 108.

Republic of South Africa, 1999, National Environmental Management Act 97. Government Gazette, Vol. 401, No. 19519.

Republic of South Africa, 1999, National Heritage Resources Act 25. Government Gazette, Vol. 406, No. 19974. 
Republic of South Africa, 1999, World Heritage Convention Act 49. Government Gazette, Vol. 414, No. 20717.

Republic of South Africa, 2003, National Environmental Management: Protected Areas Act 57. Government Gazette, Vol. 464, No. 26025

Republic of South Africa, 2004, National Environmental Management: Biodiversity Act 10. Government Gazette, Vol. 467, No. 26436.

Republic of South Africa, 2008, National Environmental Management: Integrated Coastal Management Act 24. Government Gazette, Vol. 524, No. 31884

Selier, S.J., Slotow, R., Blackmore, A. \& Trouwborst, A., 2016, 'The legal challenges of transboundary wildlife management at the population level: The case of a trilateral elephant population in southern Africa', Journal of International Wildlife Law \& Policy 19(2), 101-135. https://doi.org/10.1080/13880292.201 6.1167460
Shefi, D. \& Veth, P., 2015, 'A critical analysis and philosophical review of 'rapid reburial': The Clarence project', International Journal of Nautical Archaeology 44(2), 371-381. https://doi.org/10.1111/1095-9270.12105

Strydom, H.A. \& King, N.D. (eds.), 2009, Environmental management in South Africa, Juta and Company Ltd., Cape Town.

UNEP, 1979, Convention on migratory species of wild animals, Bonn, viewed 07 June 2018, from www.cms.int/en/convention-text

UNESCO, 1972, 'Convention concerning the protection of the world cultural and natural heritage', adopted by the General conference at its seventeenth session, Paris, viewed 16 November 1972, from https://whc.unesco.org/en/conventiontext/

UNESCO, 1995, 'Intergovernmental Committee for the Protection of the World Cultural and Natural Heritage', Operational guidelines for the implementation of the world heritage convention, UNESCO, Intergovernmental Committee for the Protection of the World Cultural and Natural Heritage, Paris, France. 